
\title{
28 Research Square \\ B4C-TiB2 Composite Ceramics with Ultra-High Fracture Toughness Fabricated by Spark Plasma Sintering
}

\section{Xingheng Yan}

Science and Technology on Advanced Ceramic Fibers and Composites Laboratory, College of Aerospace

Science and Engineering, National University of Defense Technology

Xingui Zhou ( $D$ 17801016168@163.com)

National University of Defense Technology

Honglei Wang

Science and Technology on Advanced Ceramic Fibers and Composites Laboratory, National University of Defense Technology

\section{Research Article}

Keywords: Spark plasma sintering, Boron carbide, Ti3SiC2, Fracture toughness

Posted Date: October 7th, 2020

DOl: https://doi.org/10.21203/rs.3.rs-84795/v1

License: (c) (i) This work is licensed under a Creative Commons Attribution 4.0 International License. Read Full License 


\section{Abstract}

$\mathrm{B}_{4} \mathrm{C}-\mathrm{TiB}_{2}$ composite ceramics with ultra-high fracture toughness were successfully prepared via spark plasma sintering using $\mathrm{B}_{4} \mathrm{C}$ and $30 \mathrm{vol} . \% \mathrm{Ti}_{3} \mathrm{SiC}_{2}$ as raw materials at different sintering temperatures. The results show that compared with pure $\mathrm{B}_{4} \mathrm{C}$ ceramics sintered by SPS, the flexural strength and fracture toughness are significantly improved, especially the fracture toughness has been improved by leaps and bounds. When the sintering temperature is $1900{ }^{\circ} \mathrm{C}$, the $\mathrm{B}_{4} \mathrm{C}-\mathrm{TiB}_{2}$ composite ceramic has the best comprehensive mechanical properties: hardness, bending strength and fracture toughness are $27.28 \mathrm{GPa}$, 405.11 MPa and 18.94 MPa $\mathrm{m}^{1 / 2}$, respectively. The main two reasons for the ultra-high fracture toughness are the formation of $\mathrm{TiB}_{2}$ three-dimensional network covering the whole composites, and the existence of lamellar graphite at the grain boundary.

\section{Introduction}

Boron carbide is widely used in wear-resistant parts, armor protection and aerospace ${ }^{[1-3]}$. These excellent properties are due to the strong covalent bond, but this structure also leads to the low self-diffusion coefficient of $\mathrm{B}_{4} \mathrm{C}$. Low self-diffusion ability, high melting point and the oxygen-rich layer $\left(\mathrm{B}_{2} \mathrm{O}_{3}\right)$ on the surface of $B_{4} C$ particles make it difficult to sinter $B_{4} C$ compactly, which greatly limits its application ${ }^{[4]}$.

There are three common methods to obtain high density $\mathrm{B}_{4} \mathrm{C}$ ceramics: increasing sintering temperature, applying high pressure and using additives. Increasing sintering temperature and pressure has great requirements for the equipment, so the use of additives has become the most convenient method. Metal additives are very effective for the densification of $\mathrm{B}_{4} \mathrm{C}$ ceramics, but the hardness of $\mathrm{B}_{4} \mathrm{C}$ ceramics decreases obviously with the soft metal phase ${ }^{[5]}$. $\mathrm{Ti}_{3} \mathrm{SiC}_{2}$ can react with $\mathrm{B}_{4} \mathrm{C}$ to form the second phase with high hardness, i.e. $\mathrm{TiB}_{2}$ and $\mathrm{SiC}$, which can achieve the second phase toughening effect at the same time of promoting sintering. Meanwhile, the reduction of hardness can be controlled in a small range.

The traditional hot pressing sintering of $\mathrm{B}_{4} \mathrm{C}$ needs to be kept above $2000{ }^{\circ} \mathrm{C}$ for more than $1 \mathrm{~h}^{[3]}$. SPS (Spark Plasma Sintering) is a kind of low-temperature rapid sintering process which is widely concerned. The combination of mechanical pressure, electric field and thermal field can enhance the bonding and densification of particles ${ }^{[6-8]}$. In this study, $\mathrm{B}_{4} \mathrm{C}-\mathrm{TiB}_{2}$ composite ceramics with high toughness were prepared by SPS process (using 30 vol. $\% \mathrm{Ti}_{3} \mathrm{SiC}_{2}+\mathrm{B}_{4} \mathrm{C}$ mixed powder as raw materials). In addition, the effect of sintering temperature on the microstructure and properties of $\mathrm{B}_{4} \mathrm{C}$ ceramics was also studied.

\section{Experimental Procedure}

Commercially available $\mathrm{B}_{4} \mathrm{C}$ powders (purity $99.9 \%, 1 \mu \mathrm{m}, 4.53 \mathrm{~g} / \mathrm{cm}^{3}$, Nangong Naiyate Alloy Welding Material Co., Ltd), $\mathrm{Ti}_{3} \mathrm{SiC}_{2}$ powders (purity $99.9 \%,<74 \mu \mathrm{m}, 4.53 \mathrm{~g} / \mathrm{cm}^{3}$,Nanjing Mingchang New Material Co., Ltd) were used as raw materials. The scanning electron microscope (SEM) images and X-ray 
diffraction (XRD) patterns of the as-received powders of $\mathrm{B}_{4} \mathrm{C}$ and $\mathrm{Ti}_{3} \mathrm{SiC}_{2}$ are shown in Fig. 1. It can be observed from SEM images that $\mathrm{B}_{4} \mathrm{C}$ particles have sharp edge and ladder-like surface undulation, which is a typical transgranular fracture appearance during the particle crushing process; $\mathrm{Ti}_{3} \mathrm{SiC}_{2}$ particles have larger grain size and obvious lamellar structure. It can be seen from the XRD images that the two kinds of powders are relatively pure and almost no oxide exists (the content of oxide is too small to be detected in XRD). 30 vol. $\% \mathrm{Ti}_{3} \mathrm{SiC}_{2}-\mathrm{B}_{4} \mathrm{C}$ powders were mixed for $24 \mathrm{~h}$ through a small vertical mixer at $80 \mathrm{r} / \mathrm{min}$ without adding solvent. The specimens were prepared by SPS equipment (HP D 25/4-SD, FCT Systeme $\mathrm{GmbH}$, Germany) in vacuum with $35 \mathrm{MPa}$ mechanical pressure at $1800^{\circ} \mathrm{C}, 1850{ }^{\circ} \mathrm{C}, 1900{ }^{\circ} \mathrm{C}$ and 1950 ${ }^{\circ} \mathrm{C}$ for $5 \mathrm{~min}$. The heating rate was $100{ }^{\circ} \mathrm{C} / \mathrm{min}$ and the cooling rate was $50{ }^{\circ} \mathrm{C} / \mathrm{min}$. The SPS method was used to prepare the sample under vacuum environment with $35 \mathrm{MPa}$ mechanical pressure at 1800 ${ }^{\circ} \mathrm{C}, 1850{ }^{\circ} \mathrm{C}, 1900{ }^{\circ} \mathrm{C}$ and $1950{ }^{\circ} \mathrm{C}$ for $5 \mathrm{~min}$. the heating rate was $100{ }^{\circ} \mathrm{C} / \mathrm{min}$ and the cooling rate was $50{ }^{\circ} \mathrm{C} / \mathrm{min}$.

Absolute density of $\mathrm{B}_{4} \mathrm{C}-\mathrm{TiB}_{2}$ composite ceramics were determined using the Archimedes method. Hardness was measured by a Vickers-indentation tester (Shimadzu, HMV-2TADW E, Japan) at $9.81 \mathrm{~N}$ load with a holding time of $15 \mathrm{~s}$ on the polished surface. Flexural strength was determined by three-point bending test with the span of $30 \mathrm{~mm}$ and the loading speed of $0.5 \mathrm{~mm} / \mathrm{min}$, and the specimens used in the test were $3 \times 4 \times 35 \mathrm{~mm}$ bars. SENB method was used to determine the fracture toughness of the specimens, with dimensions of $2 \times 4 \times 20 \mathrm{~mm}$ (with $2 \mathrm{~mm}$ high notch). The microstructures of the composite ceramics were characterized by X-Ray powder diffraction (XRD, X' Pert PRO-MPD, Holland Panalytical, Netherlands), scanning electron micro-scope (SEM, S-4800N, Hitachi, Japan), transmission electron microscope (TEM, JEM-2100, JEOL, Japan) and energy dispersive spectrometer (EDS, INCA, OXFORD INSTRUMENTS, England).

\section{Results And Discussion}

Fig. 2 XRD patterns of $\mathrm{B}_{4} \mathrm{C}-\mathrm{TiB}_{2}$ ceramic composites sintered at different temperatures

Fig. 2 shows the phase composition of $\mathrm{B}_{4} \mathrm{C}-\mathrm{TiB}_{2}$ ceramic composites prepared at different sintering temperatures. There is no diffraction peak of $\mathrm{Ti}_{3} \mathrm{SiC}_{2}$ in all XRD images, which indicates that $\mathrm{Ti}_{3} \mathrm{SiC}_{2}$ has completely reacted with $\mathrm{B}_{4} \mathrm{C}$ and transformed into $\mathrm{TiB}_{2}$ and $\mathrm{SiC}$ in the sintering process at four different sintering temperatures. When the temperature is above $1200{ }^{\circ} \mathrm{C}$, the following reactions occur ${ }^{[9]}$ :

$$
\begin{aligned}
& \mathrm{B}_{4} \mathrm{C}+\mathrm{Ti}_{3} \mathrm{SiC}_{2} \rightarrow 2 \mathrm{TiB}_{2}+\mathrm{TiC}+\mathrm{SiC}+\mathrm{C} \\
& \mathrm{B}_{4} \mathrm{C}+2 \mathrm{TiC} \rightarrow 2 \mathrm{TiB}_{2}+3 \mathrm{C}
\end{aligned}
$$


The reaction (1) and (2) ended at $1600{ }^{\circ} \mathrm{C}$, on the basis of the above results, the overall reaction in the system can be described as the following reaction ${ }^{[9]} \square$

$$
3 \mathrm{~B}_{4} \mathrm{C}+2 \mathrm{Ti}_{3} \mathrm{SiC}_{2} \rightarrow 6 \mathrm{TiB}_{2}+2 \mathrm{SiC}+5 \mathrm{C}
$$

TiC does not exist in the final product, appearing as an intermediate product during the whole sintering process. According to the XRD test results, the content of each phase is shown in Table 1. It can be seen that the composition of the composite ceramics changes little when sintered at different sintering temperatures, which is mainly composed of $\mathrm{TiB}_{2}$ and $\mathrm{B}_{4} \mathrm{C}$, with a small amount of $\mathrm{SiC}$ and $\mathrm{C}$. When the temperature rise, the content of $\mathrm{SiC}$ decreases and the content of $\mathrm{C}$ increases, which may be due to the slight evaporation of silicon in the sintering process. It can be inferred that the evaporation of Si also increases with the increase of temperature.

Table 1 contents of different phases in $\mathrm{B}_{4} \mathrm{C}-\mathrm{TiB}_{2}$ composite ceramics sintered at different temperatures

\begin{tabular}{|llllll|}
\hline Simple name & Sintering Temperature $\left({ }^{\circ} \mathrm{C}\right)$ & $\mathrm{TiB}_{2}$ (wt.\%) & $\mathrm{B}_{4} \mathrm{C}(\mathrm{wt} . \%)$ & $\mathrm{SiC}(w t . \%)$ & $\mathrm{C}(\mathrm{wt} . \%)$ \\
\hline BT1800 & 1800 & 30.3 & 61.4 & 5 & 3.3 \\
\hline BT1850 & 1850 & 30.1 & 61.6 & 4.7 & 3.6 \\
\hline BT1900 & 1900 & 29.6 & 61.9 & 4.2 & 4.4 \\
\hline BT1950 & 1950 & 30.6 & 61.2 & 3.5 & 4.7 \\
\hline
\end{tabular}

Table 2 Properties of ceramics prepared by different sintering processes

\begin{tabular}{|llllllll|}
\hline $\begin{array}{l}\text { Simple } \\
\text { code }\end{array}$ & $\begin{array}{l}\text { Content of } \\
\mathrm{Ti}_{3} \mathrm{SiC}_{2} \\
(\mathrm{vol. \% )}\end{array}$ & $\begin{array}{l}\text { Sintering } \\
\text { Temperature } \\
{ }^{\circ} \mathrm{C} \square\end{array}$ & $\begin{array}{l}\text { Density } \\
\left(\mathrm{g} / \mathrm{cm}^{3}\right)\end{array}$ & $\begin{array}{l}\text { Relative } \\
\text { Density } \\
(\%)\end{array}$ & $\begin{array}{l}\text { Hardness } \\
(\mathrm{GPa})\end{array}$ & $\begin{array}{l}\text { Flexural } \\
\text { Strengh } \\
(\mathrm{MPa})\end{array}$ & $\begin{array}{l}\text { Fracture } \\
\text { Toughness } \\
\left(\mathrm{MPa} \cdot \mathrm{m}^{1 / 2}\right)\end{array}$ \\
\hline B1800 & 0 & 1800 & 2.50 & 99.20 & 33.5 & 224.43 & 5.96 \\
\hline BT1800 & 30 & 1800 & 3.12 & 99.84 & 28.03 & 358.30 & 16.41 \\
\hline BT1850 & 30 & 1850 & 3.13 & 100.32 & 28.44 & 351.10 & 17.15 \\
\hline BT1900 & 30 & 1900 & 3.17 & 101.54 & 27.28 & 405.11 & 18.94 \\
\hline BT1950 & 30 & 1950 & 3.17 & 101.44 & 28.16 & 398.01 & 17.53 \\
\hline
\end{tabular}

Table 2 shows the mechanical properties of the samples prepared by different sintering processes. The sample $\mathrm{B} 1800$ is pure $\mathrm{B}_{4} \mathrm{C}$ ceramic sintered by SPS as comparative group, whose hardness, bending strength and fracture toughness are $33.5 \mathrm{GPa}, 224.43 \mathrm{MPa}$ and $5.96 \mathrm{MPa} \cdot \mathrm{m}^{1 / 2}$, respectively. The density 
of simples BT1800 to BT1950 is slightly higher than that of pure $B_{4} C$ ceramic sintered by SPS. Because of the slight evaporation of silicon, the density of $\mathrm{B}_{4} \mathrm{C}-\mathrm{TiB}_{2}$ composite ceramic is even slightly higher than the theoretical density. Fig.3(a) shows the variation of relative density and hardness of $\mathrm{B}_{4} \mathrm{C}-\mathrm{TiB}_{2}$ composite ceramic versus sintering temperature. The relative density becomes larger with the increase of temperature, reaches the highest point at $1900{ }^{\circ} \mathrm{C}$, and decreases slightly at $1950{ }^{\circ} \mathrm{C}$. When the ceramic composition is basically the same, the density is the key factor affecting the hardness of ceramics, while the ceramics sintered at $1800{ }^{\circ} \mathrm{C}$ and above are almost dense (The relative density of all simples are above $99.8 \%$ ), so the influence of sintering temperature on the hardness of ceramics is negligible. The hardness of the sample containing $30 \mathrm{vol} . \% \mathrm{Ti}_{3} \mathrm{SiC}_{2}$ decreases to a certain extent compared with that of pure $\mathrm{B}_{4} \mathrm{C}$. However, due to the high hardness of the main second phase $\mathrm{TiB}_{2}$ formed by the reaction, the hardness of the composite ceramics still remains at a high level between $27.18 \mathrm{GPa}$ and $28.44 \mathrm{GPa}$.

Fig.3(b) shows the variation of flexural strength and fracture toughness of B4C-TiB2 ceramics with sintering temperature. Simple and BT1850 have similar flexural strength and fracture toughness, and the properties of BT1900 are obviously higher than the former two. This change trend is consistent with the relative density in Fig.3(a). Fig.4(a)-(d) are the SEM pictures of fracture appearance of samples BT1800 to BT1950 in turn. Fig.4(b) shows there are some large-size $B_{4} C$ grains in the samples sintered at 1850 ${ }^{\circ} \mathrm{C}$, resulting in a small decrease in the flexural strength of the samples sintered at $1800{ }^{\circ} \mathrm{C}$. The comparison of Fig.4(a)-(c) shows that the samples sintered at $1800{ }^{\circ} \mathrm{C}, 1850{ }^{\circ} \mathrm{C}$ and $1900{ }^{\circ} \mathrm{C}$ have similar grain sizes (excluding a small part of large grains in Fig.5(b)), so the significant increase of density at $1900^{\circ} \mathrm{C}$ is the reason for the improvement of flexural strength and fracture toughness of sample BT1900. Compared with BT1900, the bending strength and fracture toughness of BT1950 are decreased, especially the latter. The main reason for that is the obvious grain growth of $B_{4} C$ as shown in Fig.5(d), and the secondary reason is the slight decrease of the relative density as shown in Fig.3(a). Fig.4(f) is the BSE image of the ceramics sintered at $2000^{\circ} \mathrm{C}$. It can be clearly seen that if the temperature is further increased, the grains grow furthermore, which is not conducive to the integrated mechanical properties of the $\mathrm{B}_{4} \mathrm{C}-\mathrm{TiB}_{2}$ composite ceramic. Moreover, when the sintering temperature is $2000{ }^{\circ} \mathrm{C}$, the raw materials reacted with graphite mold and damage it. So, the bending strength and fracture toughness reach the maximum values of $405.11 \mathrm{MPa}$ and $18.94 \mathrm{MPa} \cdot \mathrm{m}^{1 / 2}$ when the sintering temperature is $1900{ }^{\circ} \mathrm{C}$. Compared with the fracture appearance of pure $\mathrm{B}_{4} \mathrm{C}$ ceramic (Fig. 4 (e)), the fracture surface of the simples with additive $\mathrm{Ti}_{3} \mathrm{SiC}_{2}$ (Fig. 4(a)-(d)) is much rougher, showing a mixed fracture mode. Intergranular fracture and transgranular fracture correspond to the rough and flat surface in the figure respectively ${ }^{[10]}$. In Fig.4, the dark gray flat area is the $\mathrm{B}_{4} \mathrm{C}$ matrix, and the light gray rough area is $\mathrm{TiB}_{2}$ particles, which indicates that in $\mathrm{B}_{4} \mathrm{C}-\mathrm{TiB}_{2}$ composite ceramics, the fracture mode of $\mathrm{B}_{4} \mathrm{C}$ phase and $\mathrm{TiB}_{2}$ phase is the transgranular fracture and intergranular fracture respectively.

Fig.3 Relative density and mechanical properties of the $\mathrm{B}_{4} \mathrm{C}-\mathrm{TiB}_{2}$ composite ceramics sintered at different temperatures 
Fig.4 (a)-(d) SEM images of $\mathrm{B}_{4} \mathrm{C}-\mathrm{TiB}_{2}$ composite ceramics sintered at $1800{ }^{\circ} \mathrm{C}, 1850{ }^{\circ} \mathrm{C}, 1900{ }^{\circ} \mathrm{C}$ and $1950{ }^{\circ} \mathrm{C}$ in turn; (e) SEM image of pure $\mathrm{B}_{4} \mathrm{C}$ ceramic sintered at $1800^{\circ} \mathrm{C}$; $(\mathrm{f}) \mathrm{BSE}$ image of $\mathrm{B}_{4} \mathrm{C}-\mathrm{TiB}_{2}$ composite ceramic sintered at $2000{ }^{\circ} \mathrm{C}$

Fig. 5 shows the BSE images of the $\mathrm{B}_{4} \mathrm{C}-\mathrm{TiB}_{2}$ composite ceramic prepared by SPS at $1900{ }^{\circ} \mathrm{C}$ for $5 \mathrm{~min}$. It can be seen from Fig.5(a) that there are $\mathrm{TiB}_{2}$ particles with different sizes from nanometer-scale to micron-scale dispersed in the $\mathrm{B}_{4} \mathrm{C}$ matrix. Due to the mismatch of thermal expansion coefficients of $\mathrm{B}_{4} \mathrm{C}$ and $\mathrm{TiB}_{2}\left(\mathrm{~B}_{4} \mathrm{C}: 4.5 \times 10^{-6} \mathrm{k}^{-1} ; \mathrm{TiB}_{2}: 8.1 \times 10^{-6} \mathrm{k}^{-1}\right)^{[11]}$, there is large residual stress at the interface of the two phases, which induces the crack deflection along the grain boundary and prolongs the crack propagation path, which greatly improves the toughness. The nano $\mathrm{TiB}_{2}$ particles embedded in the $\mathrm{B}_{4} \mathrm{C}$ matrix can introduce internal stress, which will strengthen the $\mathrm{B}_{4} \mathrm{C}$ matrix by lattice distortion effect, and can also nail the dislocations and hinder their movement. In addition, as shown in Fig.5(c), the nano $\mathrm{TiB}_{2}$ and $\mathrm{SiC}$ particles at the grain boundary of $\mathrm{B}_{4} \mathrm{C}$ can also strengthen the grain boundary and prevent the crack growth. Fig.5(b) is the BSE image of $\mathrm{TiB}_{2}$-SiC aggregates, in which the dark gray, medium gray and light gray phases are $\mathrm{B}_{4} \mathrm{C}, \mathrm{SiC}$ and $\mathrm{TiB}_{2}$, respectively. In this multiphase mixing region with a large amount of $\mathrm{SiC}$, there is adverse stress effects that have a negative effect on flexural strength ${ }^{[12]}$. However, the $\mathrm{TiB}_{2}{ }^{-}$ $\mathrm{SiC}$ aggregates can expand the crack propagation path and change the crack propagation direction to consume the crack growth energy, which is helpful to improve the toughness. The crack propagation path in this area is shown in Fig.5(d).

Fig.5 BSE images of different structures of the $\mathrm{B}_{4} \mathrm{C}-\mathrm{TiB}_{2}$ composite ceramic sintered at $1900{ }^{\circ} \mathrm{C}$

Table 3 shows the mechanical properties of $\mathrm{B}_{4} \mathrm{C}-\mathrm{TiB}_{2}$ composite ceramics prepared by different starting materials and sintering methods in recent two years ${ }^{[13-17]}$. Compared with these works, the flexural strength $(405.11 \mathrm{MPa})$ of the simple that we sintered by SPS at $1900{ }^{\circ} \mathrm{C}$ is in the middle to a low level, but the fracture toughness $\left(18.94 \mathrm{MPa} \cdot \mathrm{m}^{1 / 2}\right)$ is much higher than the fracture toughness shown in the table, which can be described as a leap forward improvement. By making an in-depth comparative study of the differences between our work and the work of other researchers, we find that there are two fundamental reasons for the excellent fracture toughness of our $\mathrm{B}_{4} \mathrm{C}-\mathrm{TiB}_{2}$ composite ceramics:

The first is the formation of a three-dimensional network of $\mathrm{TiB}_{2}$ in the composites. In the area as shown in Fig.5(f), $\mathrm{B}_{4} \mathrm{C}$ and $\mathrm{TiB}_{2}$ are occluded and interlaced, and $\mathrm{TiB}_{2}$ forms a network structure in the $\mathrm{B}_{4} \mathrm{C}$ matrix. In the low magnification backscatter image Fig.5(e), we can find out that this network structure accounts for a large proportion of the whole material composition, and it does not exist in isolation. Links are formed between each small network, connecting a larger network structure covering the whole composite as a whole. At the same time, this network divides $\mathrm{B}_{4} \mathrm{C}$ concentrated area and surrounds each one, so that there is no large area of continuous $\mathrm{B}_{4} \mathrm{C}$ phase in the material, which is very unfavorable to the toughness of the composite. With higher interlacing degree of $\mathrm{TiB}_{2}$ and $\mathrm{B}_{4} \mathrm{C}$ phases, the cracks need to bypass more multiple two-phase interfaces, change the direction for more times, and disperse into 
more small cracks in the process of extension. Therefore, the overall three-dimensional network structure greatly improves the fracture toughness of the $\mathrm{B}_{4} \mathrm{C}-\mathrm{TiB}_{2}$ composite ceramics.

Table 3 Comparison of the properties of the $\mathrm{B}_{4} \mathrm{C}-\mathrm{TiB}_{2}$ composite ceramics reported in recent years and produced by us

\begin{tabular}{|c|c|c|c|c|c|}
\hline $\begin{array}{l}\text { Serial } \\
\text { no. }\end{array}$ & Starting powder & $\begin{array}{l}\text { Relative } \\
\text { Density (\%) }\end{array}$ & $\begin{array}{l}\mathrm{K}_{\mathrm{IC}} \\
\left(\mathrm{MPa} \cdot \mathrm{m}^{1 / 2}\right)\end{array}$ & $\begin{array}{l}\text { Flexural strength } \\
(\mathrm{MPa})\end{array}$ & $\begin{array}{l}\text { Ref. } \\
\text { (year) }\end{array}$ \\
\hline 1 & $\mathrm{~B}_{4} \mathrm{C}+5$ wt. $\%\left(\mathrm{Ti}_{3} \mathrm{SiC}_{2}+\mathrm{Si}\right)$ & -- & 5.61 & 457.6 & $\begin{array}{l}{[13]} \\
(2019)\end{array}$ \\
\hline 2 & $\mathrm{~B}_{4} \mathrm{C}+20 \mathrm{~mol} \% \mathrm{TiB}_{2}$ & 97.9 & 3.7 & -- & $\begin{array}{l}{[14]} \\
(2020)\end{array}$ \\
\hline 3 & $\begin{array}{l}\mathrm{B}_{4} \mathrm{C}+15 \text { wt. } \% \mathrm{SiC}+20 \\
\mathrm{~mol}^{2} \mathrm{TiB}_{2}\end{array}$ & 98.6 & 4.2 & 343.8 & $\begin{array}{l}{[15]} \\
(2020)\end{array}$ \\
\hline 4 & $\mathrm{~B}_{4} \mathrm{C}+30$ wt. $\%\left(\mathrm{TiB}_{2}+\mathrm{Si}\right)$ & 99.6 & 5.77 & 531.2 & $\begin{array}{l}{[16]} \\
(2018)\end{array}$ \\
\hline 5 & $\begin{array}{l}\mathrm{B}_{4} \mathrm{C}+6.45 \text { vol. } \% \mathrm{SiC}+7.78 \\
\text { vol\% } \mathrm{TiB}_{2}\end{array}$ & 99.62 & 6.38 & 632 & $\begin{array}{l}{[17]} \\
(2019)\end{array}$ \\
\hline 6 & $\mathrm{~B}_{4} \mathrm{C}+30$ vol. $\%\left(\mathrm{Ti}_{3} \mathrm{SiC}_{2}\right)$ & 101.54 & 18.94 & 405.11 & $\begin{array}{l}\text { This } \\
\text { work }\end{array}$ \\
\hline
\end{tabular}

Another reason is the existence of $\mathrm{C}$, which exists in the form of graphite. With the increase of reaction temperature, the content of $C$ increased, and its effect on the properties of the materials cannot be ignored. The graphite formed by the reaction of $\mathrm{Ti}_{3} \mathrm{SiC}_{2}$ and $\mathrm{B}_{4} \mathrm{C}$ exists in the grain boundary in the form of bands, as shown in the TEM image Fig.6. The existence of the graphite layer reduces the bonding strength of the interface, which has an adverse effect on the hardness and strength of the composite ceramics $^{[18]}$. But on the other hand, its existence can limit grain growth. In the cooling process, microcracks are produced under the effect of interfacial stress produced by different thermal expansion coefficients, and according to the mechanism of microcrack toughening, it is beneficial to improve the toughness of the material. Combined with the data in Table 1 and Fig3(b), it can be found out that the fracture toughness of the material is positively related to the graphite content before the abnormal grain growth occurs at $1950^{\circ} \mathrm{C} \square$

Fig.6 TEM image of the $\mathrm{B}_{4} \mathrm{C}-\mathrm{TiB}_{2}$ composite ceramic sintered at $1900{ }^{\circ} \mathrm{C}$

\section{Conclusions}

The ultra-high toughness and full density $\mathrm{B}_{4} \mathrm{C}-\mathrm{TiB}_{2}$ composite ceramics were prepared by SPS with the addition of $30 \mathrm{vol} . \% \mathrm{Ti}_{3} \mathrm{SiC}_{2}$. Sintering temperature has a great influence on its microstructure and 
mechanical properties, mainly reflected in the sensitivity of density and grain size to temperature. The change of sintering temperature has little effect on the hardness of $\mathrm{B}_{4} \mathrm{C}-\mathrm{TiB}_{2}$ composite ceramics. With the increase of sintering temperature, both bending strength and fracture toughness increase and then decrease. When the sintering temperature is $1900{ }^{\circ} \mathrm{C}$, the $\mathrm{B}_{4} \mathrm{C}-\mathrm{TiB}_{2}$ composite ceramic has the maximum relative density and kept the small grain size, and obtain the best comprehensive mechanical properties: hardness, bending strength and fracture toughness are $27.28 \mathrm{GPa}, 405.11 \mathrm{MPa}$ and $18.94 \mathrm{MPa} \cdot \mathrm{m}^{1 / 2}$, respectively. The fracture toughness of $\mathrm{B}_{4} \mathrm{C}-\mathrm{TiB}_{2}$ composite ceramics has been greatly improved at the expense of some hardness and bending strength. In $\mathrm{B}_{4} \mathrm{C}-\mathrm{TiB}_{2}$ composite ceramics, the fracture mode is a mixture of transgranular fracture and intergranular fracture. The leap of fracture toughness is attributed to the formation of the $\mathrm{TiB}_{2}$ three-dimensional network in the $\mathrm{B}_{4} \mathrm{C}$ matrix, and the layered graphite exists at the grain boundary.

\section{References}

1. Suri AK, Subramanian C, Sonber JK et al (2010) Synthesis and consolidation of boron carbide: a review. Int Mater Rev 55(1):4-40

2. Domnich V, Reynaud, et al. Boron Carbide: Structure, Properties, and Stability under Stress. 2011; 94(11):3605-3628

3. Suri AK, Subramanian C, Sonber JK et al (2013) Synthesis and consolidation of boron carbide: a review. Int Mater Rev 55(1):4-40

4. Francois Thévenot (1990) Boron carbide-A comprehensive review 6(4):205-225

5. Xie KY, Toksoy MF, Kuwelkar K et al (2014) Effect of Alumina on the Structure and Mechanical Properties of Spark Plasma Sintered Boron Carbide. J Am Ceram Soc 97(11):3710-3718

6. Olivier G, Jesus, et al. Field-Assisted Sintering Technology/Spark Plasma Sintering: Mechanisms, Materials, and Technology Developments. 2014

7. Munir ZA, Anselmi-Tamburini U, Ohyanagi M (2006) The effect of electric field and pressure on the synthesis and consolidation of materials: A review of the spark plasma sintering method. Journal of Materials Science 41(3):763-777

8. Chaim R, Chevallier G, Weibel A et al (2017) Grain growth during spark plasma and flash sintering of ceramic nanoparticles: a review. Journal of Materials Science 53(5):3087-3105

9. He P, Dong S, Kan Y et al (2016) Microstructure and mechanical properties of B4C-TiB2 composites prepared by reaction hot pressing using Ti3SiC2 as additive. Ceram Int 42(1):650-656

10. Wen Q, Tan Y, Zhong Z et al (2017) High toughness and electrical discharge machinable B 4 C-TiB 2 $\mathrm{SiC}$ composites fabricated at low sintering temperature. Materials Science Engineering: A 701:338343

11. Zhang X, Zhang Z, Wang W et al. Preparation of B4C composites toughened by TiB2-SiC agglomerates. 2016:S0955221916304824 
12. Moshtaghioun BM, Ortiz AL, Gómez-García D et al. Toughening of super-hard ultra-fine grained B4C densified by spark-plasma sintering via SiC addition. 2013; 33(8):1395-1401

13. Song Q, Zhang ZH, Hua ZY et al (2019) Microstructure and mechanical properties of super-hard B4C ceramic fabricated by spark plasma sintering with $(\mathrm{T} 3 \mathrm{SiC} 2+\mathrm{Si})$ as sintering aid. Ceram Int 45(7):8790-8797

14. Liu Y, Wu X, Liu M et al (2020) Microstructure and mechanical properties of B4C-TiB2-SiC composites fabricated by spark plasma sintering. Ceram Int 46(3):3793-3800

15. Liu Y, Li Z, Peng Y et al (2020) Effect of sintering temperature and TiB2 content on the grain size of B4C-TiB2 composites. Materials Today Communications 23:100875

16. Yin SP, Zhang ZH, Cheng XW et al (2018) Spark plasma sintering of B4C-TiB2-SiC composite ceramics using B4C, Ti3SiC2 and Si as starting materials. Ceram Int 44(17):21626-21632

17. Zhang X, Zhang Z, Liu Y et al (2019) High-performance B4C-TiB2-SiC composites with tuneable properties fabricated by reactive hot pressing. J Eur Ceram Soc 39(10):2995-3002

18. Moshtaghioun BM, García DG, Domínguez-Rodríguez A. High-temperature plastic deformation of spark plasma sintered boron carbide-based composites: The case study of B4C-SiC with/without graphite (g). 2016; 36(5):1127-1134

\section{Figures}



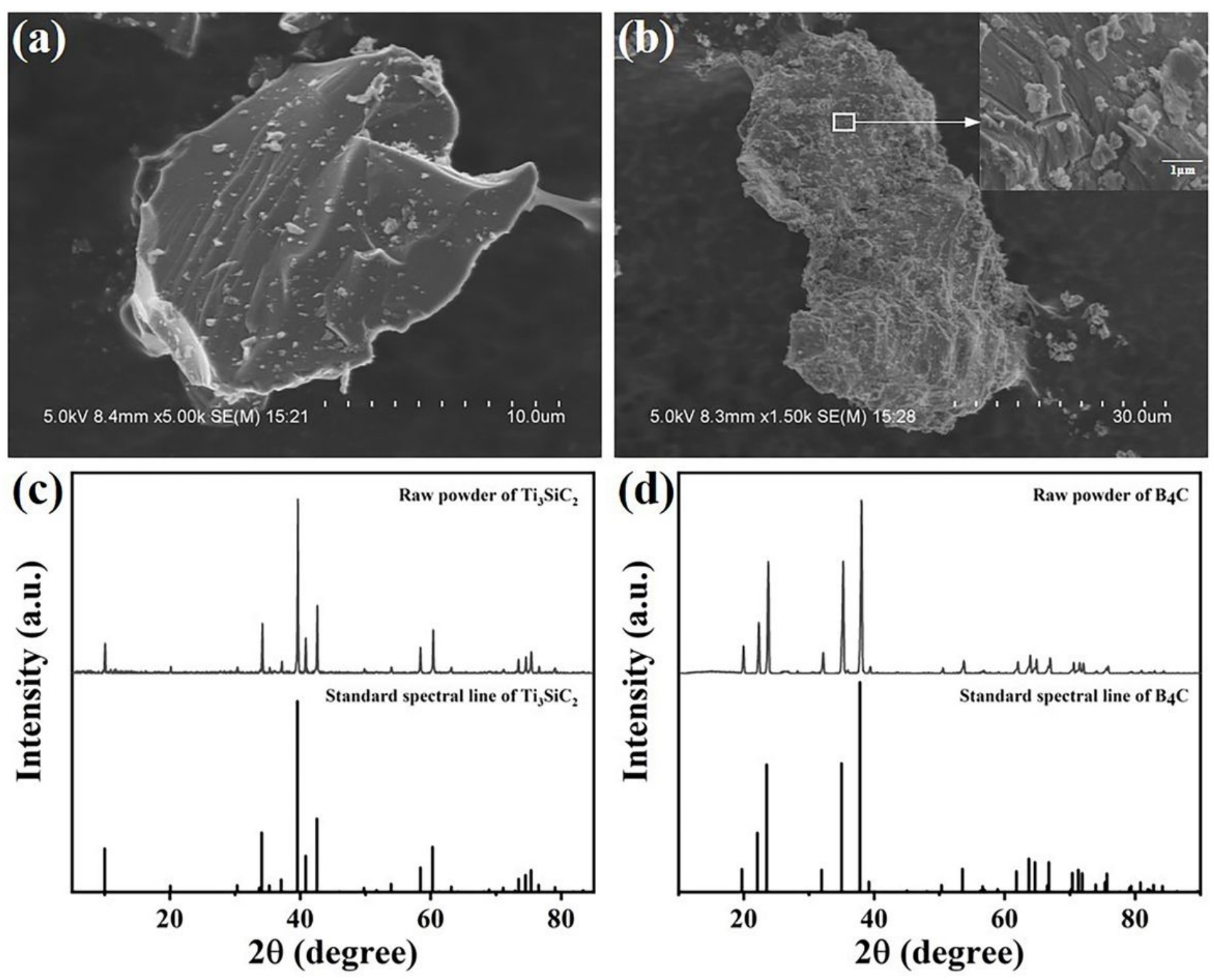

Figure 1

SEM images and XRD patterns of raw powders 

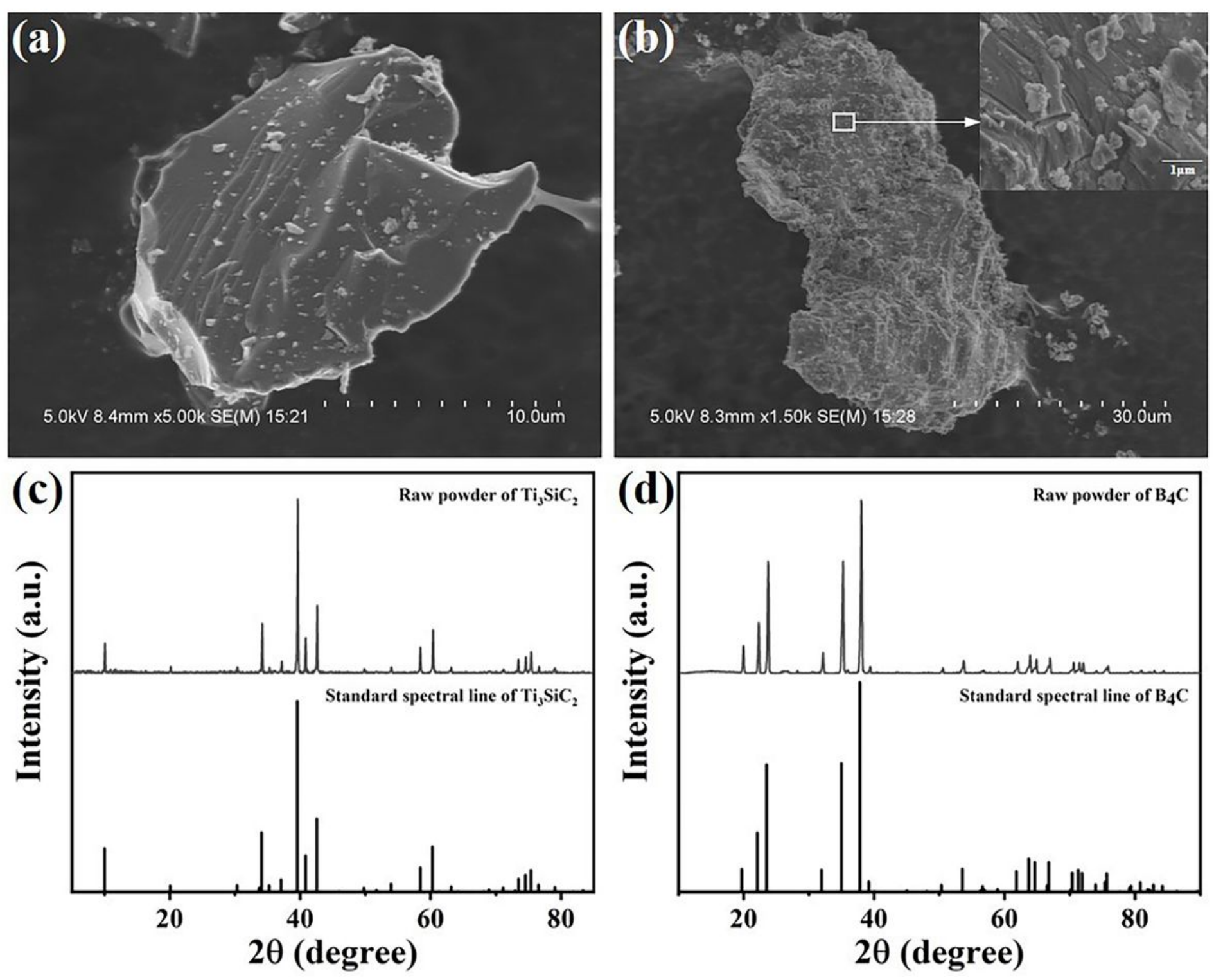

Figure 1

SEM images and XRD patterns of raw powders 


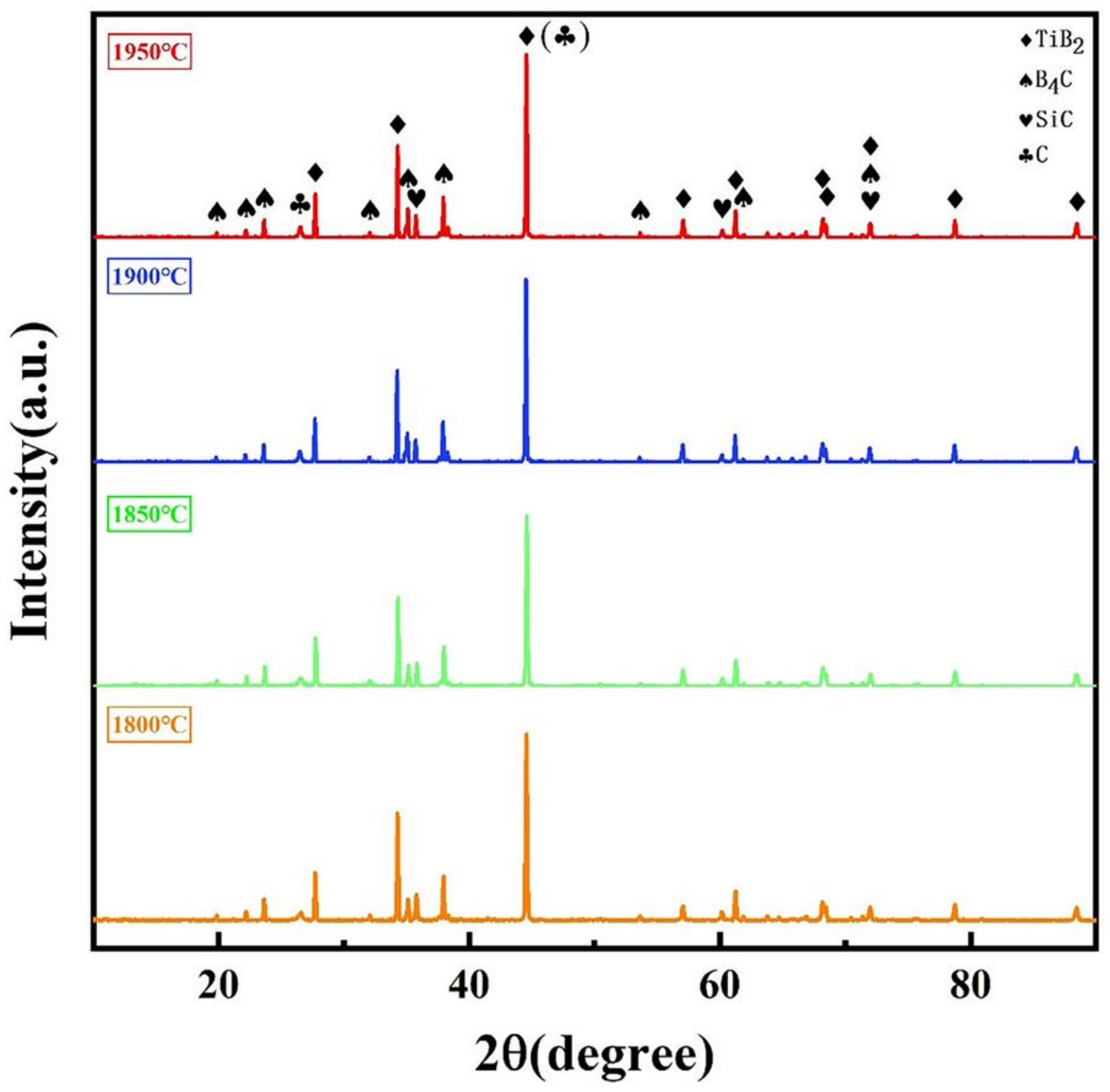

Figure 2

XRD patterns of B4C-TiB2 ceramic composites sintered at different temperatures 


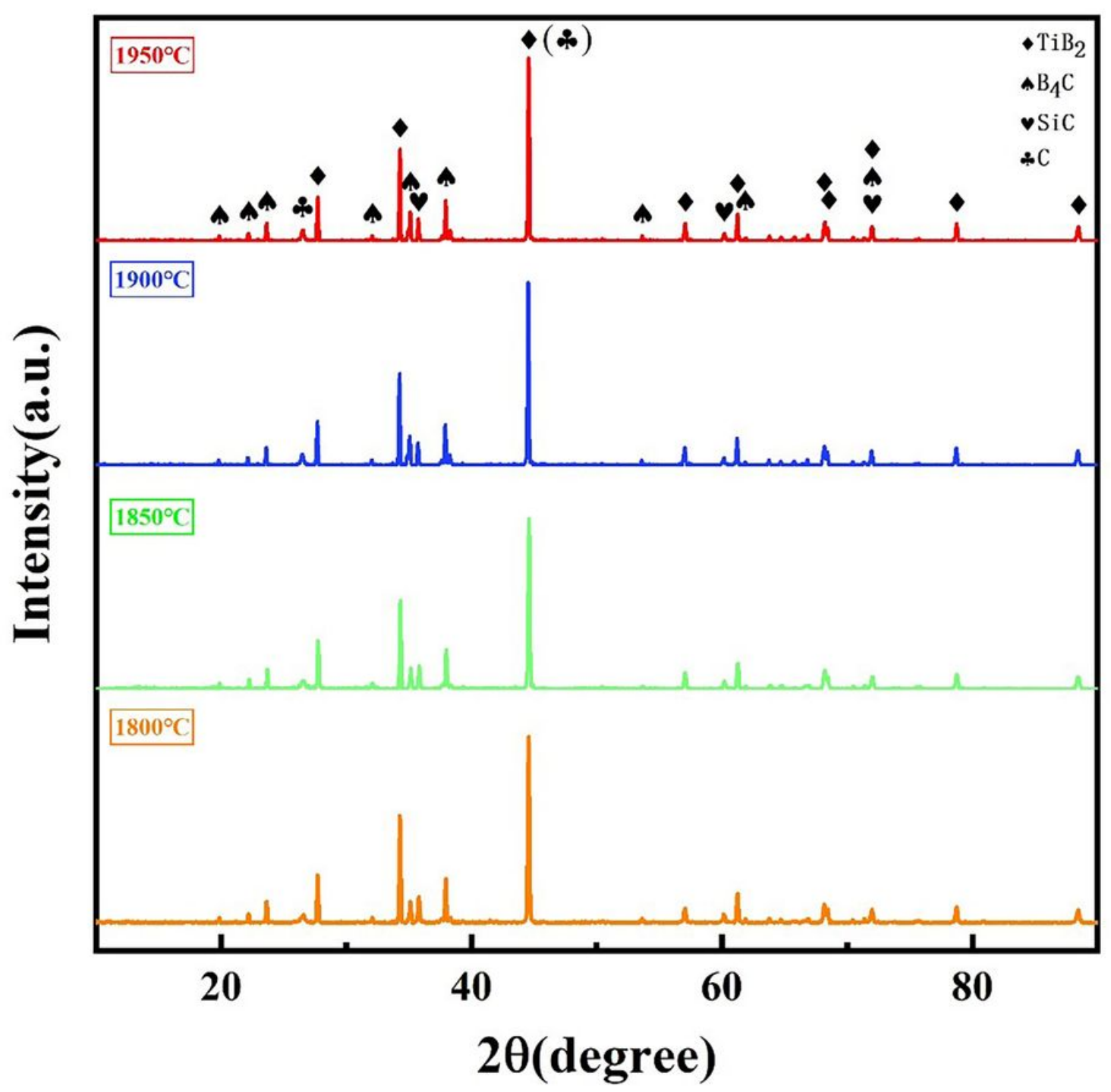

Figure 2

XRD patterns of B4C-TiB2 ceramic composites sintered at different temperatures
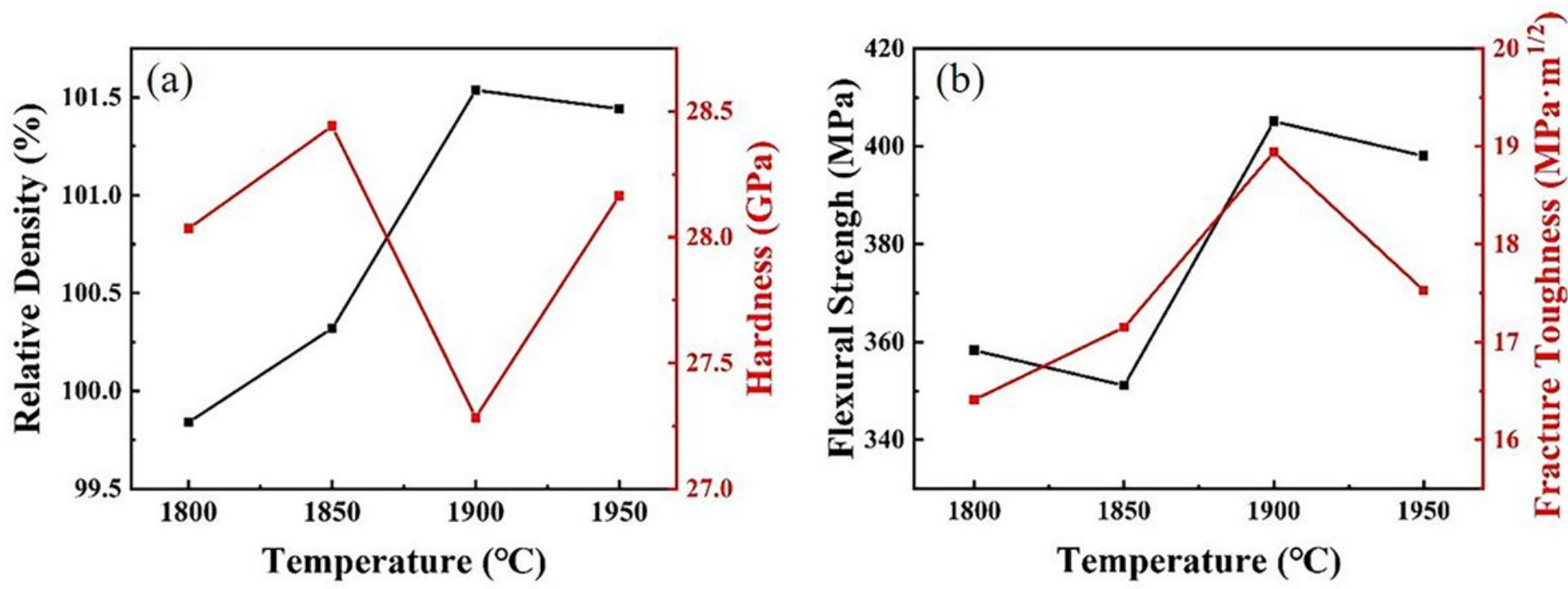
Figure 3

Relative density and mechanical properties of the B4C-TiB2 composite ceramics sintered at different temperatures
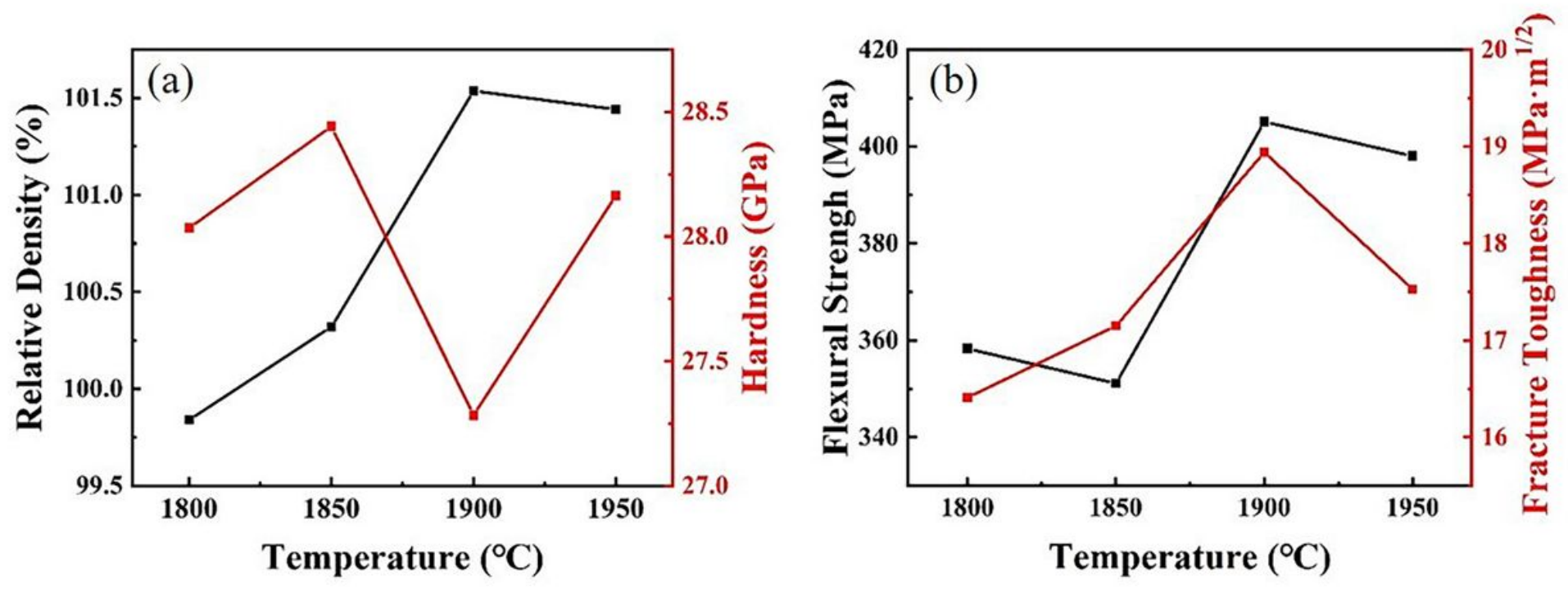

Figure 3

Relative density and mechanical properties of the B4C-TiB2 composite ceramics sintered at different temperatures 


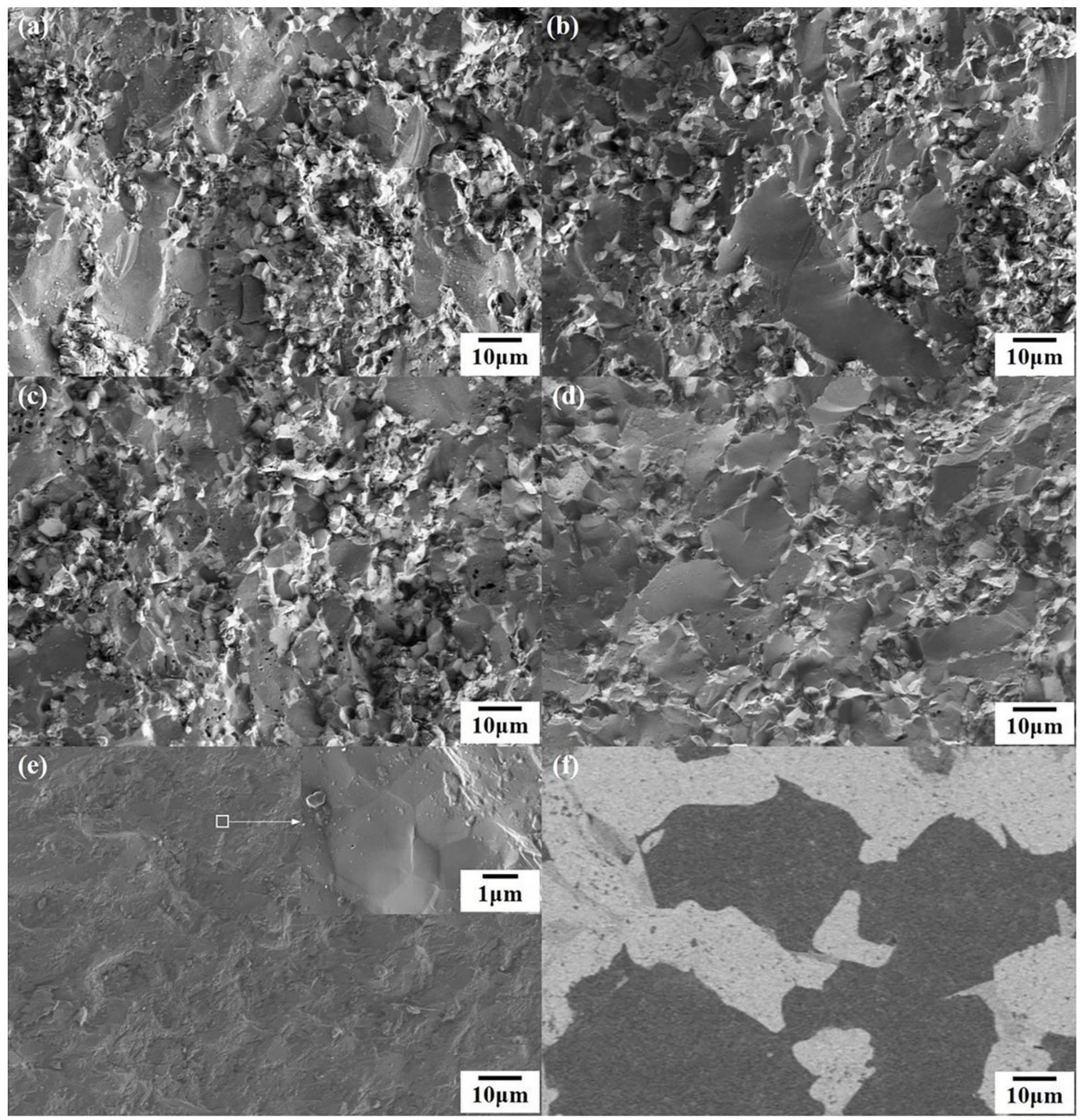

\section{Figure 4}

a)-(d) SEM images of B4C-TiB2 composite ceramics sintered at $1800{ }^{\circ} \mathrm{C}, 1850{ }^{\circ} \mathrm{C}, 1900{ }^{\circ} \mathrm{C}$ and $1950{ }^{\circ} \mathrm{C}$ in turn; (e) SEM image of pure B4C ceramic sintered at $1800^{\circ} \mathrm{C}$; (f) BSE image of B4C-TiB2 composite ceramic sintered at $2000^{\circ} \mathrm{C}$ 


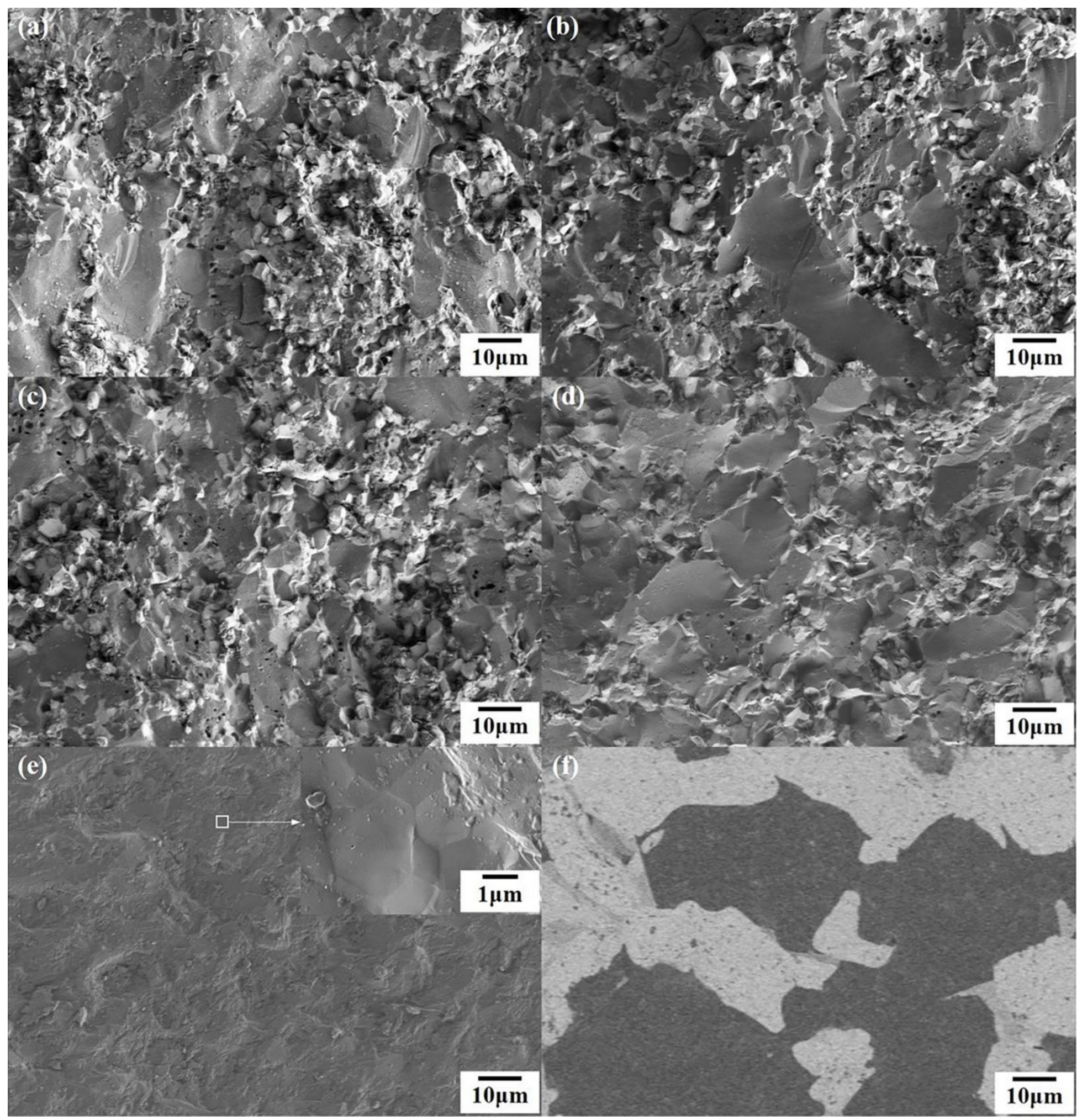

\section{Figure 4}

a)-(d) SEM images of B4C-TiB2 composite ceramics sintered at $1800{ }^{\circ} \mathrm{C}, 1850{ }^{\circ} \mathrm{C}, 1900{ }^{\circ} \mathrm{C}$ and $1950{ }^{\circ} \mathrm{C}$ in turn; (e) SEM image of pure B4C ceramic sintered at $1800^{\circ} \mathrm{C}$; (f) BSE image of B4C-TiB2 composite ceramic sintered at $2000^{\circ} \mathrm{C}$ 


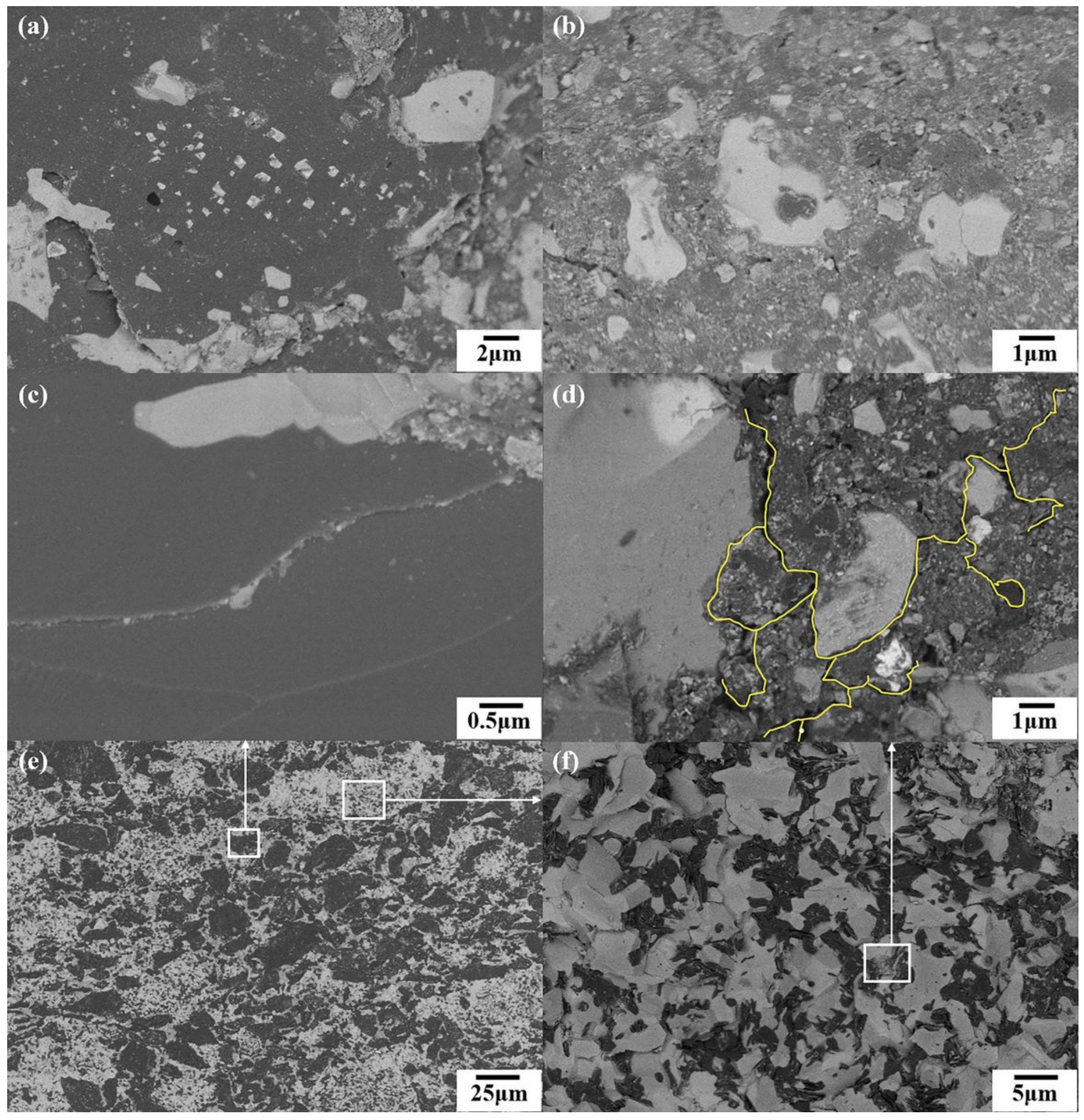

Figure 5

BSE images of different structures of the B4C-TiB2 composite ceramic sintered at $1900{ }^{\circ} \mathrm{C}$ 


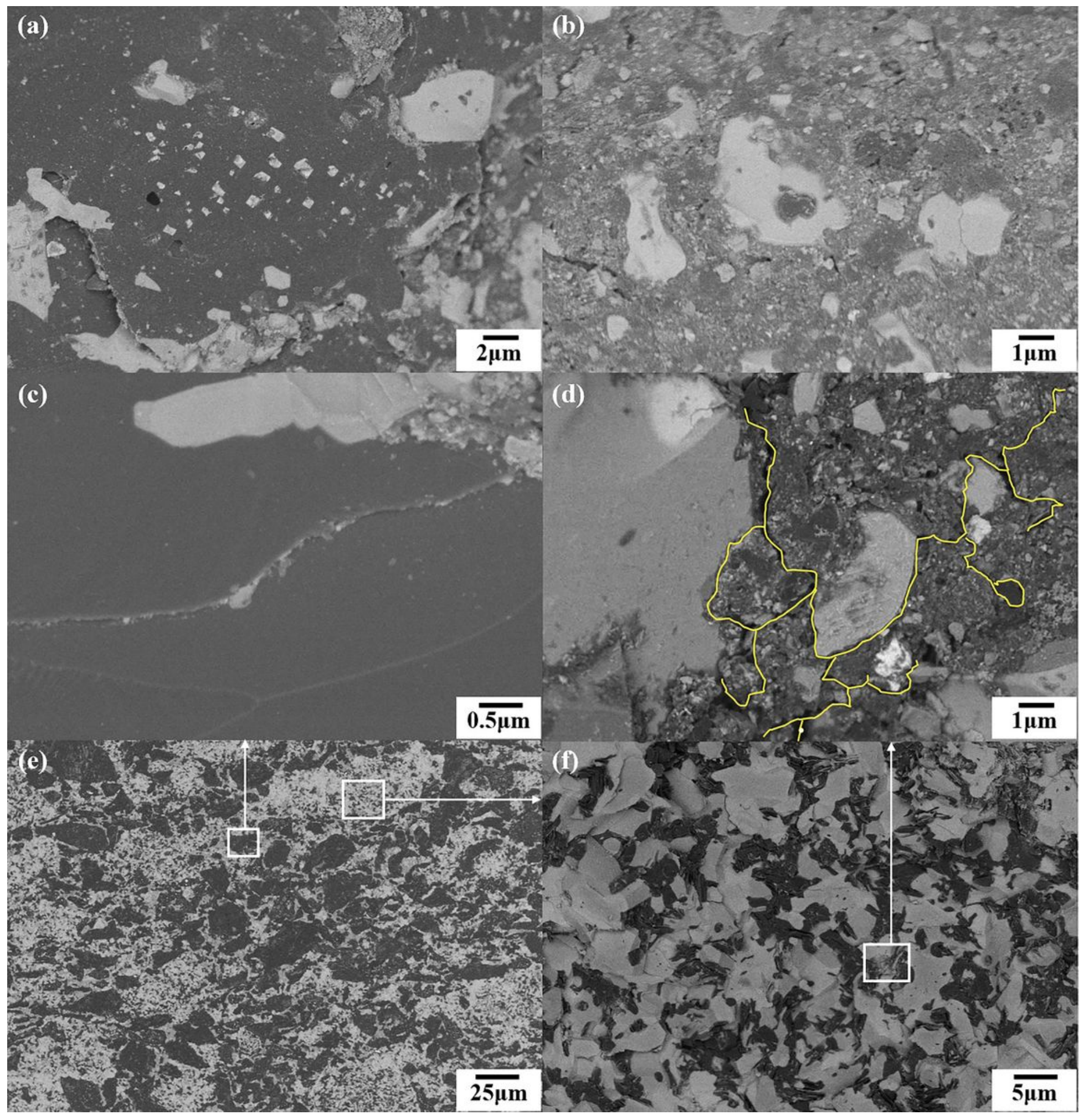

Figure 5

BSE images of different structures of the B4C-TiB2 composite ceramic sintered at $1900{ }^{\circ} \mathrm{C}$ 


\section{$\mathrm{TiB}_{2}$}

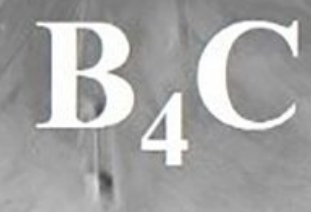

\section{$\mathrm{TiB}_{2}$}

$0,5,155$

\section{Figure 6}

TEM image of the B4C-TiB2 composite ceramic sintered at $1900{ }^{\circ} \mathrm{C}$ 


\section{$\mathrm{TiB}_{2}$}

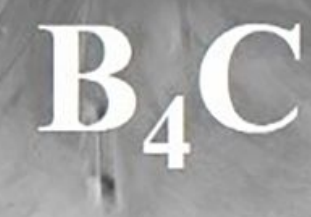

\section{$\mathrm{TiB}_{2}$}

$0,5,155$

\section{Figure 6}

TEM image of the B4C-TiB2 composite ceramic sintered at $1900{ }^{\circ} \mathrm{C}$ 